\title{
The Polylogue ProJeCt
}

\author{
SHORTMIND
}

\author{
Katarzyna BAZARniK, ERIK BINDERVOet, Tim CONLEy, RobBERT- \\ Jan Henkes, Erika Mihálycsa, Elena Păcurar, Guillermo \\ Sanz Gallego, Fritz Senn, EnRico Terrinoni, Jolanta \\ WAWRZYCZKA
}

\begin{abstract}
The aim of this collaborative project [edited by $\mathrm{F}$. Senn, E. Mihalycsa and J. Wawrzycka], the work of ten authors and covering more than ten languages, is to chart the possibilities of translation to recreate in the TL texts, the anomalous, elliptic, pre-grammatical, inchoative forms that became almost a signature mark of the Joycean interior monologue, and which here are called 'shortmind'. It therefore addresses such issues as indeterminacy, (anomalous) word order, punctuation, ellipsis, polysemy, ungrammaticality, linguistic sub-standards etc., and examines the (un)willingness of translation texts to breach ingrained rules and norms of (syntactic, narrative) control, correctness and coherence, in the TL culture.
\end{abstract}

Keywords: Anomalous Structures; James Joyce; Linguistic Substandards; Non-normative Syntax; Sliding Signi-fication.
Resumo: O objetivo deste projeto colaborativo [editado por F. Senn, E. Mihálycsa e J. Wawrzycka], trabalho de dez autores e que cobre mais de dez línguas, é catalogar as possibilidades de tradução ao se recriar nos textos da língua alvo as formas anômalas, elípticas, pré-gramaticais e incoativas que se tornaram como que uma marca distintiva do monólogo interior joyceano, chamadas aqui de "shortmind". Trata, portanto, de tópicos como indeterminação, ordem (anômala) das palavras, pontuação, elipse, polissemia, agramaticalidade, sub-padrões linguísticos, etc, e examina a (má)vontade de textos em tradução de romper com regras e normas de controle, correção e coerência (sintáticas e narrativas) arraigadas na cultura alvo.

Palavras-chave: Estruturas anômalas; James Joyce; sub-padrões linguísticos; sintaxe não normativa; significação movediça. 
$\mathrm{G}$ lobally, most readers of Ulysses - and their name must be legion - do not face it in its original (mainly) English guise but in some linguistic transformation. It is worth speculating what those foreign readers actually absorb in content, mood, overtones, vibrations. Two statements live in open conflict side by side: Literature cannot be translated. Literature has been and is constantly being translated - and it may be true of Ulysses, only more so. What are the results of translating Ulysses? What remains, somehow, the same, and what changes? The paradox is that everything has to change and yet is intended to be the same.

Some perennial issues of translation are intensified in Joyce and demand our renewed attention. In this context we decided to convene practitioners as well as critical onlookers for a translation workshop ("TransWork") that would focus on specific, possibly extreme, Joycean niceties. For once, the workshop was not to consist of a series of presentations, but concrete problems and examples, sent out in advance, would be intently discussed. In their nature all issues selected for our analysis were tricky ones to start with. The existing solutions were to be scrutinized and possibilities considered. Special emphasis would be laid on the opportunities as well as on the handicaps of the various languages - such as syntactic constraints, inflexion, word order, compounds, neologisms, idioms, etc.

The workshop took place from May 8 to 11, 2010, and gathered Joyce translators and scholars from Finland, Germany, Hungary, Italy, the Netherlands, Romania and Switzerland ${ }^{1}$ for intensive sessions on textual features that, we thought, had so far been given relatively little attention in Joyce translation scholarship: "Shortmind", Musical/Sound Effects, Quotations and Errors. The discussion of two of those issues, Shortmind and Errors were continued in correspondence between various participants who addressed them here in written commentaries.

"Shortmind" is a term devised by Fritz Senn to designate a salient feature of Joyce's interior monologue where a thought is seen emerging in its pre-grammatical, pre-syntactic, inchoative, groping, associative semi-shape. Translators tend to smooth out and change such a provisional assembly of thoughts in statu nascendi, an initial jumble, into neat, grammatical, punctuation-controlled sentences. Some of the examples are discussed here as "impact sentences" (whether they are actual sentences or not).

The second category relates to the very Joycean feature of errors, mistakes, misunderstandings that are often embedded in the intricate structure of Ulysses: "Throwaway", "word/world", "tender Achilles", etc.

The editors of the enterprise, Erika Mihálycsa, Jolanta Wawrzycka, and Fritz Senn, invited the original participants as well as a few additional recruits to contribute their observations and commentaries on the pre-selected phrases, sentences and passages. Since the Zurich workshop participants included retranslators of Ulysses whose work appeared in the course of 2012 - Erik Bindervoet and Robbert-Jan Henkes's Dutch Ulixes, Enrico Terrinoni's Italian Ulisse, Leevi Lehto's Finnish Ulysses, and the new Hungarian Ulysses (the work of a four-strong team of Joyceans whose co-ordinator András Kappanyos

\footnotetext{
${ }^{1}$ Regrettably, there was no French participation since Bernard Hoepffner, one of the members of Jacques Aubert's translation team of Ulysse (2004), was detained by an untimely accident.
} 
and chief Joycean scholar, Marianna Gula, brought their own dilemmas and translation versions to the Zurich dissection table) - we have good reasons to believe that many of the points raised during the workshop eventually fed into the final form that Joyce's Weltalltag-novel took in those respective languages.

\section{Shortmind}

In this section, a few samples will be offered non-systematically to show how translations deal with pre-formulated or as yet inadequately formulated thoughts and phrases, with the implied questions of whether adequate reproductions of such structures in target languages are possible, and to what degrees of accuracy. A book like Ulysses, notoriously not conforming to precedents, thereby offers a wide scope for innovative ventures.

One handicap of translation is that what looks, at first blush, uncoordinated, in statu nascendi (or cogitandi) will be attributed to a translator's lack of command in the target language. Something may strike reviewers (on the lookout for gaffes) as "not correct German", or Finnish or Russian, unaware that Joyce's English, as early responses testify, might not have passed the muster of the critical eyes of purist schoolmasters or editors. Reviewers are more tolerant about deviations from norm by a creative writer like Joyce than about those of his translators who are not generally given the analogous benefit of doubt. Translators of Joyce, moreover, are beset by so many problems and intricacies that the rendering of pre-formulated phrases need not be, and certainly has not been, a priority or even worth consideration. In the attempt to "get things right" that were originally not right or normal become almost automatically prone to apparent improvement. So now we move to the examples and language-by-language discussions.

\section{O! Exhausted that female has me. (13.1253)}

In what we will call here "impact" and "process" sentences, Joyce skirts traditional syntax and prefers to front certain words/structures that impinge on the mind, as is the case with the example below, when Bloom at the end of his long day, and following his physical relief at the sight of Gerty MacDowell, internally exclaims: O! Exhausted that female has me (13.1253). The stimulus seems to be a feeling of exhaustion, which triggers off the rest of the thought. If "exhausted" is at the end of the sentence, the (pre?)articulated expression is turned into a distanced reflection. Could these, in themselves correct, sentences be amended?

\section{GERMAN(ic) and Romance languages (Fritz Senn)}

It seems - in my own subjective and perhaps debatable reading - that an initial physical awareness of exhaustion (almost in an original sense of "emptied out", Lat. ex-haurire, that is to say, "drained") finds expression before 
its cause is looked into. One might imagine a simple "O! Exhausted [I am]"2, followed by "And it was that female that did it." Many translators do not treat it that way:

\author{
Das Weib hat mich ganz erschöpft $(\mathrm{G} / \mathrm{G} 430)$ \\ Hat mich das Frauenzimmer fertiggemacht(G/W 534) \\ Wat heeft dat vrouwmens me uitgeput (D/V 441) \\ Que cette jeune personne m'a mis en plat (F/M 375) \\ Hvor har der kvindfolk gjort mig træt (Da/B 352)
}

A different process is called up, a reasoned reflection, a statement made from more distance, with perhaps a touch of blame. The emphasis is on the action, not its result. In Bloom's movement the cause is appended after the first impression. An idiomatic expression ("mis en plat") misses the physical exhaustion and a feeling of emptiness.

Some translators do put the exhaustion before its source, but not in an emphatic front position:

\footnotetext{
Me ha dejado exhausto esa hembra (S/S 402)

M'ha proprio sfinito quella femmina (I/DA 515)

Hon har minsann mattat ut mig. (Sv/W 387)

Elle m'a vidé la femelle (F/A 549)
}

At least three translations show that it is possible to start with the internal experience, an internal observation, more in accordance with the inner process which is here considered significant:

Ehausto que essa mulherzinha me deixou ( $\mathrm{Po} / \mathrm{H} 432)$

Exhausto esa mujer me ha dejado (S/T 438)

Svuotato quella donna m'ha (I/T 377)

An earlier observation is almost analogous: "Drained all the manhood out of me, little wench" (13.1101). As early as 1927 Georg Goyert followed the word order and used an active verb in the front position: "Sog die ganze Männlichkeit aus mir heraus, die kleine Hexe" (G/G 425); much later Hans Wollschläger reversed the process: "Hat doch die ganze Männlichkeit aus mir

\footnotetext{
${ }^{2}$ The identical word would preserve a tenuous link with "Exhausted, breathless ... (O!)" in "Sirens", where the exhaustion is caused by laughter (11.177).

${ }^{3}$ I was once rightly rapped on the knuckles for not back-translating the translations that I quoted, and it is not done here. The assumption is that in Romance and Germanic languages the sense or the direction can be guessed. It is illusory, furthermore, to assume that, when intricate or insoluble issues are at stake, the versions quoted could be rendered (by way of a translation!) with the necessary philological precision and with an awareness of idiomatic nuances.
} 
gesogen, die kleine Hexe" (G/W 528), putting the cause before the effect. In French the action precedes in shortened form: "M'a ôté tous mes moyens, la petite garce" (F/A 543), and even more so in "M'a vidé, la mâtine" (F/M 370); as it happens, both idiomatically oriented French versions indeed do drain the "manhood" out of the sentence. It is possible, though not necessary and cannot be proved, that "Drained" is, first, an awareness of Bloom's state ("Drained I am") that leads to the cause ("Drained me she has"), in which case it would be even more important to give the word its impact position.

\title{
DUTCH (Erik Bindervoet and Robbert-Jan Henkes)
}

\author{
O! Wat heeft dat vrouwmens me uitgeput. (D/V 441) \\ O! Wat heeft dat vrouwmens me uitgeput! (D/C\&N 404) \\ O! Uitgeput heeft dat vrouwtje me. (D/B\&H 449, future 4th ed.)
}

In Dutch, the impact, as in English, is keenly felt, if you translate the words in the order that Joyce proposes (or really prescribes). The impact of a different syntax is, in fact, felt so keenly, that both previous Dutch translators (Vandenbergh 1969; Claes \& Nys 1995) have hesitated to turn the sentence into "Joycean" Dutch.

Both have: Wat heeft dat vrouwmens me uitgeput, Vandenbergh ending in a full stop (441), and Claes \& Nys, feeling perhaps that the impact was a little lost, providing an exclamation mark: Wat heeft dat vrouwmens me uitgeput! (404). This is a way of compensating, agreed, but the sentence now reads markedly different. With an exclamation mark, it sounds as if Bloom were, well, exclaiming it, almost happily, while the sentence with the overturned word order has a more sighing and resigned quality to it. After all, he shot his wad and post coïtum, or even eiaculationem seminis, omne animal tristis est, except cocks and women. (To be considered for a future, fourth edition of our translation: we have an unaccountable exclamation mark as well, that could be discarded.)

And it is so easy in Dutch to maintain this quality, with exactly the same method that Joyce uses: Uitgeput heeft dat vrouwtje me (450). It wouldn't be the usual written word order in Dutch, but wer are here almost exactly halfway through Ulysses, and a translator may expect the reader to appreciate the Joycean stylistic novelties, if he has come this far (the reader, not the translator). Still, and this happens regularly, translators are scared to do it "wrong" for fear they may be held responsible for it: "Ooh, they don't even know Dutch!" With many translators, and Claes \& Nys are two of them, this impulse to normalize has become almost second nature.

During the Zürich workshop in May 2010, this "impact sentence" did pose serious problems in other languages than our DoubleDutch. In Russian, as in most Slavic languages, the word order is much more free, on account of the wealth of inflexions. So any rummaging there would remain less noticeable, although putting a word first in Slavic does give some kind of stress. And what to do in Arabic, where the first word is usually the verb? A solution proposed 
was to add a word like "really" or something, to make up for the otherwise barely noticeable impact.

In French, we were told, a mucked-about word order is well nigh impossible: "It would sound like Racine." Well, what's wrong with that, we thought, you get another layer, another overtone for free in translation: here's what you can win instead of losing all the way, but we kept our peace.

But you have to start educating the readers somewhere and make them accustomed to Joycean originality, don't you? When the previous Italian translation came out, Fritz reminded us, the reviews were panning: the translation didn't change Italian as much as Joyce had changed English. And that is really the high task of the translator: to recreate the effect. To do in your language what Joyce did in his. Here the translator gets his missive, his noble commission, from the highest authority (J.J. himself) to teach his people a new grammar, and in a superhuman effort to resist, though it be going against his every grain and fibre, the nearly automatic impulse to fit, by hammer and saw, by nail and claw, his curiosities into the Procrustacean bed of applied, received normal grammar.

\section{ITALIAN (Enrico Terrinoni)}

Svuotato quella donna m'ha (I/T 2012 377)

M'ha proprio sfinito quella femmina (I/DA 523) ${ }^{4}$

In my translation, I decided to keep the original word order here, which in standard Italian is slightly defamiliarizing. It would sound quite right, though, in Italian dialects such as Sardinian, or - as I learned during the Zurich TransWork workshop - Swiss Italian. Anyway, since in my translation the whole co-text is never regionally connoted, no Italian speaking reader could virtually see this single instance as an attempt to reproduce a regional dialect. Rather, it would just sound quite odd and strangely phrased, as the original is in my view, giving perhaps the impression that the sentence is actually divided into two parts - svuotato (i.e., emptied) + quella donna $m$ 'ha (i.e., that woman has me). This does not happen in De Angelis's translation. The decision to keep the original word order makes my text quite as ambiguous as the original, I believe, especially in the way it respects the pause between the two parts of the sentence. I went for donna rather than femmina, as my predecessor did, precisely because the latter seems to me to be too regionally-connoted, it being used mainly in the Naples area as a synonym for woman; in the rest of the country femmina is much more used for animals. On the contrary, donna works very much like the English female here, in that it conveys the very sense of that mocked-at completeness of femininity I spot in the reference to Gerty. However, the good thing about the previous translation - which by the way, by

\footnotetext{
${ }^{4}$ All references to the previous Italian translation of Ulysses by Giulio De Angelis (revised by Giorgio Melchiori, Carlo Izzo, Glauco Cambon), published for the first time in 1960, will be to the reprint of the original edition (Milano: I Meridiani, 1999), for copyright reasons mainly, not to the Oscar Mondadori revised edition, which includes De Angelis's revisions based on the Gabler Ulysses (Milano: Oscar Mondadori, 1999).
} 
changing the word order puts everything in place despite the text's ambiguity is the choice of sfinito, which would be literally closer to "exhausted" than my svuotato - a much more sexually charged lexical choice.

\section{SPANISH (Guillermo Sanz Gallego)}

¡Oh! Me ha dejado exhausto esa hembra. (S/S 402)

¡Ah! Esa hembra me ha dejado agotado. (S/V 386)

¡Oh! Exhausto esa mujer me ha dejado. (S/T 438)

A couple of differences can be noticed in the three translations into Spanish. First of all, the reader of the original text observes a peculiar syntax that is characteristic of Bloom's interior monologue. Such constructions emphasize the protagonist's excitement. Subirat's and Valverde's versions lack such shift in the word order. However, Tortosa strengthens Bloom's mood at the end of the Sandycove scene in "Nausicaa" by keeping the structure of the original. Like in Joyce's text, the third translation contains the disordered agglomeration of words that appear in Bloom's stream of consciousness. Therefore, unlike the other translators, Tortosa has been able to reproduce the Joycean style of Bloom's interior monologue in their version.

Secondary issues to consider in the translation of this excerpt are found at the lexical level, such as the reference to "female" that appears in the first two versions as hembra, whereas the most recent one has opted for mujer. The option mujer is a more neutral term and can be used in a broader number of contexts. The expression hembra found in the two former translations is more sexually charged and, therefore, seems more appropriate to keep the equivalence with the original text in terms of register.

A final point of interest lies in the translation of interjections into Spanish. According to the Diccionario de uso del español de María Moliner (Editorial Gredos: Madrid, 1998), the interjection "oh" is used to express admiration, surprise, interest, joy, and pain, whereas "ah", apart from all these contexts, is also applied to satisfaction. Accordingly, Valverde's choice of interjection seems the most suitable for the context.

\section{ROMANIAN (Elena Păcurar)}

$\mathrm{O}$ ! M-a dat gata femela asta. (Ro/I II 47)

[O! That female has nonplussed me.]

The 1984 Romanian translation by Mircea Ivănescu leaves no room for interpretation: the sentence idiomatically translates (sexual) exhaustion in terms of quasi-romantic conquest. There is almost nothing literally exhausting in the translated version, but only an explicit sense of strong impression exerted by the woman onto the man. The Romanian idiom a da gata echoes a spiritual/intellectual/emotional impact resulting in a state of bewilderment or perplexity, and not the physical empowerment of the English sentence. 
Adjective fronting with emphatic effect, though, was previously possible in the Romanian version of "Tired I feel now." (13.1101): "Obosit mai sînt." [Tired I am], with a very similar meaning, structure and emphasis.

\section{POLISH, RUSSIAN (Jolanta Wawrzycka)}

Och! Wyczerpala mnie ta kobieta (P/S 296)

[O! Exhausted me that woman (has)].

Although the literal back translation reads somewhat clumsily, the Polish translation, with its frontal wyczerpała ["exhausted"] reflects very well the sense of the original, in tune with Joyce's emphasis, first, on the effect of Bloom's action/behavior and second, on the trigger that effected it. However, because of conjugation, the Polish verb for "exhaust" - wyczerpac - has its culprit ascribed immediately: the ending, "-ata", third-person singular feminine past tense of wyczerpać, gives the agency away: it was the female who did the exhausting. Thus Słomczyński's syntactical faithfulness falls victim to grammatical necessity. The possibility that Bloom is just exhausted because he's been "at it again" ( $U$ 13.746) - never mind the trigger - is not to be surmised from the blame game we encounter in Polish. ${ }^{5}$ It would be possible to say: "Wyczerpany jestem [I am exhausted] przez tą kobietę [by this woman]."

Ох! Измочалила меня эта дева (R/H\&H 296)

[och, exhausted me that maiden]

This sentence has the same grammatical/syntactic structure as the Polish translation, though it introduces a rather archaic дева, i.e., "maid" or "maiden."

"Lestrygonians" is particularly rich in inchoative interior monologue passages that illustrate a thought process in not-yet-grammatical raw form. One of these is Bloom's reflection on seeing Simon Dedalus's daughter Dilly:

Underfed she looks too. (8.41)

Wygląda na niedożywioną (P/S 116)

[(She) looks undernourished/underfed]

An opportunity to front "underfed" was forfeited by the translator here. Bloom notices Dilly's flimsy dress first, then her malnourished appearance too - thus a progression of perception-cum-reflection is registered, a particularly Bloomian feature. In Polish, Dilly's dress and her malnourished appearance are noted in succession, list-like. The effect of depth introduced by "too" can be achieved by adding te $\dot{z}$, "too", either before or after "(she) looks"- wyglada: the translation would read as: Na niedożywiona też wyglada/wyglada też.

\footnotetext{
${ }^{5}$ Incidentally, "At it again" appears twice in Ulysses, the second instance in Molly's thoughts about not waking up Bloom and "have him at it again slobbering" ( $U$ 18.903). In "Nausicaa", the idiomatic "At it again?" is rendered in Polish as "Znowu to?" (P/S, 287) [Again this?] and it is generic enough to apply to any situation and to acquire contextual emphasis. Molly in Polish is careful not to wake Bloom lest "he will be doing it again [and will] slobber all over me" (“znowu bẹdzie to robił obślini mnie całą" P/S, 542).
} 
И вид совсем отощавший (R/H\&H 116)

[And appearance completely turned gaunt]

The Russian sentence has a nice economy to it: tight and precise wording of continuation, rather than just addition to, the previous phrase, by courtesy of "and."

In the next example of impact effect, the Polish translation follows Bloom's thinking much closer: "Kill me that would" (8.376) is successfully rendered as Zabitoby mnie to $(\mathrm{P} / \mathrm{S} 123)$ [kill me it/that would], but then again, the Polish phrasing here is much more standard than Joyce's fronting of "kill." Bloom's thoughts are on Mrs. Purefoy, of course, but because the "kill" phrase is preceded by Bloom's thoughts of a child groping for the way out during birth and followed by his relief that Molly's births were relatively easy, one could well understand the "that" as referring to Bloom's own birth (it would kill him to grope for the way out - which it didn't; his birth was not breeched) or to him having to give birth (which it doesn't in "Circe"). The Polish translation supports both possibilities.

But in Russian we have Меия бы ето убило (R/H\&H 123) [lit. "me this would kill," meaning, "this would kill me"], a corrective syntax that conforms to a colloquial way of putting it.

As was the case with "underfed" above, the next two examples also illustrate translatorial choices that depart from Joyce's rather prominent examples of the impact that a word can have on a thought that trails behind that word:

\footnotetext{
Phosphorus it must be done with (8.21)

Robią to chyba przy pomocy fosforu (P/S 116)

[(They) do it probably with the help of phosphorus]
}

In the Polish rendition, the unspecified agency of robia - "(they) do it", and a tentative chyba - "probably", lends a speculative rather than assertive ring to Joyce's phrasing. For it is the Bloomian denotation that matters here: Pepper's trick of representing ghostly presence on stage (Gifford, 157) must be achieved using phosphorus or else there would be no "bluey greeny" phosphorescence to it. To approximate Joyce's phrasing, Polish would have to use "phosphorus" in frontal emphatic position and emphasize certainty: Fosforem to sie napewno robi ["With phosphorus it is surely done"] - in Polish, phosphorus is in the ablative/instrumental case, as it ends up in Bloom's usage, in spite of its deceitfully nominative posturing. The Polish solution I suggest above is actually present in the Russian translation:

\footnotetext{
Фосфором ето наверно делют (R/H\&H 116)

["With phosphorus they surely do it"].
}

In another example, the impact phrase "Esthetes they are" (8.544), has derisive dimensions and "esthetes" comes emphasized in Bloom's mind because a second earlier he cannot come up with the right word: "Those literary ethereal people they are all. Dreamy, cloudy, symbolistic" - and tasteless enough to have their stockings too loose over their ankles. In Polish 
translation we have To esteci (P/S 127) [Those are esthetes], a plain indicative mode, where Esteci to $s a$ [Eshtetes they are] or just Esteci would add a tone and a distancing emphasis that we find in the original. The Russian translation offers just that: Эстеты (R/H\&H 127) [Esthetes].

\title{
HUNGARIAN (Erika Mihálycsa)
}

\author{
Oh! Kimerített ez a kis némber. (H/G I 309) \\ [Oh! Exhausted (has me) this little female.] \\ Ó! Ez a nőstény kikészített. (H/Sz 474) \\ [O! This female (has) finished me.] \\ Ó! Kikészített ez a kis nőstény. (H/“C””365) \\ [O! Finished (has me) this little female.]
}

Hungarian, an agglutinating non-Indo-European language belonging to the Finno-Ugric family, has a singularly flexible word order where fronting as a rule denotes (slight) emphasis, as well as settling the theme-rheme relation. Theoretically thus the odd word order of the original can be unproblematically recreated, as evidenced in the literal rendering of the first translation by Endre Gáspár (1947) and the new, 2012 version, a thorough re-editing and partial retranslation carried out by a team of Joycean scholars under the supervision of András Kappanyos, both of which start on the verb (whose postpositions encode tense, person and the direct object "me"). It is only the 1974 text by Miklós Szentkuthy that opts for the more usual word order, starting on the subject rather than on the verb. Yet the difference in effect between the latter and the other two Hungarian versions does not even approach the breach between the original and the (presupposed) normative English, "That female has exhausted me". Paradoxically, precisely because of the flexibility of Hungarian word order, the original's impact, its non-standard quality - associated both with spoken Hiberno-English where such frontings are common, and with a prevalent pattern in Bloom's interior monologues that seem to dramatize the order of perception - is mitigated, if not lost entirely: both Gáspár's and the "Corrected" translations read as perfectly common usage, a far cry from the self-estranging idiosyncrasy of the original. Curiously, rendering the effect of Bloomian "shortmind" may prove even more of a crux for Hungarian translators than for translators into most Germanic languages who are bound by strictures of word order: such effect largely depends on a certain amount of preventedness, on the (partial) overcoming of syntactic obstacles and regulations rather than relying purely on (more or less) emphatic fronting in Hungarian - which merely produces another perfectly normative and usual utterance.

\section{Nectar imagine it drinking electricity (8.927)}

In this example, "nectar" seems to occur first in the mind, triggering off an association to electricity and the immaterial food of the gods; the resulting porous, elliptic construction forces the limits of syntax and asks for the readers' 
filling-in. All translations reproduced here front "nectar" - however, a comma, pause, indicates the sort of narrative control that is absent from the original. Some translations introduce a subject and most tend to "improve" on the original sentence by normalizing it.

\section{GERMAN(ic) and Romance languages (Fritz Senn)}

Separating commas can serve to turn a seeming muddle into disjointed bits, at cost of dividing a quick jumbled flow of thoughts into distinct entries. "Nectar /imagine it / drinking electricity" (8.927, slashes have been added for demonstration). Most translators opt for a comma after "nectar", and take care of the rest without inconvenience:

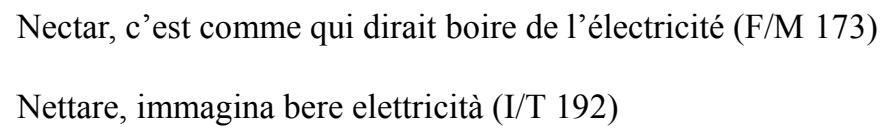

German demands even two commas, in accordance with its rules of punctuation:

Nektar, glaube, als tränke man Elektrizität (G/G 201)

Nektar, das ist wie stell dir vor, du trinkst Elektrizität (G/W 247)

The result is more acceptable and less tentative and the chopped-up sequence contrasts with the even flow of the original; moreover, a subject ("man", "du") has been added.

The translators are in good company. Danis Rose in his Reader's Edition ${ }^{6}$ sets "Nectar," off with a comma too. Robert Gogan in his Ulysses Remastered" ${ }^{7}$ goes a step further in inserting a new start after a full stop: "Nectar, imagine it. Drinking electricity" (148). It is the aim of these editors to make the text more absorbable or, in Lestrygonian terms, easier to digest. Whatever one's opinion about such interferences, they point out some apparent, perhaps troubling, irregularity or disturbances.

\section{DUTCH (Erik Bindervoet and Robbert-Jan Henkes)}

Nectar, moet zijn of je elektriciteit drinkt: godenmaaltijd. (D/V 206)

Nectar is of je elektriciteit drinkt: godenspijs. (D/C\&N 190)

Nectar zoiets als electriciteit denk ik drinken: godenvoedsel. (D/B\&H 210)

\footnotetext{
${ }^{6}$ JOYCE, James. Ulysses. A Reader's Edition. Edited by Danis Rose. London: Picador. 1997.

${ }^{7}$ JOYCE, James. Ulysses. Remastered by Robert Gogan. Straheens, Music Ireland Publications, 2012
} 
There are already too many commas in the world, so why introduce one if it wasn't there in the first place, i.e., the original? Most translators probably put it there to render a service to the reader, while it should be the other way round: the effort of the reader finally makes the book what it is. The effect in the previous Dutch translations is something of a pretty aphorism, not of ongoing thinking going on.

The Vandenberg translation even sounds like an ad: "Nectar, must be like drinking electricity," in the order of "For relaxing times, make it Santory time," which would have been funny if the translator had had the guts to change the comma into a colon. (As a translator you have to be a bit of a commafucker, as we say in Dutch. The colonfucker is yet to be invented, in literaribus that is.)

The Claes \& Nys translation does away with the comma, very nicely so, but they replace it with even more explanation and verbalisation: "Nectar is like drinking electricity." This is definitely not what it is or should be or do. A bite-size chunk to keep the readers at bay and the troublesome questions away. A good advice to translators: first try to do it as literally as possible and see if it holds up. If you did that in Dutch, you would get something like this: Nectar stel je voor electriciteit drinken ("Nectar imagine drinking electricity"). But then you would miss out on the very crucial "it" (as in "drinking it"), which causes the bump in the thinking and reading process. So we gradually evolved to: Nectar zoiets als electriciteit denk ik drinken: "Nectar something like I think drinking electricity," which recreates the bump in the "I think," though is maybe a bit too self-referential. And introducing: the subject, which is not so nice, at first, until you realize that the "I think" in Dutch is something of a throwaway (very much like "imagine"). You could do away with the subject (Nectar zoiets als electriciteit drinken denk), but then the bump is gone too and it would become a bit too regional to our ears. But, again, maybe something for the future fourth edition?

\section{FRENCH (Tim Conley)}

Nectar, c'est comme qui dirait boire de l'électricité. (F/M 173)

Le nectar, c'est comme si tu buvais de l'électricité. (F/A 258)

Both of the French versions introduce a copula that is pointedly absent from the original, and thereby dilute the startling metaphor into a simile, even into received wisdom ("as one says"), and despite Bloom's good stock of such stuff, it would seem unfair to deny him any originality here. So perhaps we might surrender the elegance of phrasing so often demanded by French and aim for abruptness: "Nectar imaginez bouvant de l'électricité." It might even be argued that the article "de 1"" is unnecessary, since Bloom is thinking not of a quantity of electricity but of electricity as a phenomenon, as an absolute (just as I am inclined to agree with Morel's leaving out the article before "nectar"). 


\section{ITALIAN (Enrico Terrinoni)}

Nettare, immaginati di bere elettricità. (I/DA 241)

Nettare, immagina bere elettricità (I/T 192)

I put a comma there for a single reason: it allows for the text to be read in many different ways. In so doing, rather than a proper grammatical subject, "Nectar" becomes almost a vocative. I take the direct object - "it" - to refer to the action of drinking electricity, while the exhortation - "imagine" - I imagine to be referred to either the speaker - or rather, the thinker - or to possible readers, hearers, or mind readers. In fact, as in the original, I do not put any virtual constraint on the interpretation of the passage, and, unlike my predecessor, I avoid using the suffix pronoun - $t$ i in immaginati, i.e., "you imagine". Syntactically, though, and only on a purely theoretical level, both our versions allow for other, quite odd, interpretations that can be formulated, like for instance that "Nectar" is the addressee of the exhortation to drink electricity - but this is much too far-fetched to be taken seriously.

\section{ROMANIAN (Elena Păcurar)}

Nectarul; închipuie-ți, să bei electricitate; hrana zeilor. (Ro/I I 210)

[Nectar; imagine that, drinking electricity; gods' food.]

Here, as in other fragments that, in the original, aim at preserving syntactic or semantic obscurity, the Romanian version inserts graphic clarifications. The two semicolons separate both the subject (nectar) and its apposition (gods' food); in between, the Romanian language facilitates the understanding of a hypothetical formulation both with the help of an imperative form (inchipuie-ți: 'imagine that') and that of the Romanian subjunctive form (să bei). The translation pauses graphically and turns the sentence into a more reader-friendly, because clarifying, experience. Again, as in the previous example, there is no room for interpretation.

\section{POLISH (Katarzyna Bazarnik)}

Nektar, wyobraź sobie, że pijesz elektryczność: pożywienie bogów” (P/S 197).

Like many other translations, the Polish one also preserves the fronting of "nectar", and in fact follows the original sequence of words: "Nektar, wyobraź sobie, że pijesz elektryczność: pożywienie bogów" (P/S 197). However, it orders the internal structure of the utterance by separating with commas a parenthetical clause "wyobraź sobie" [literally: "imagine to yourself" or "depict it in your mind"]. The grammatical ordering continues in the following subordinate object clause: "że pijesz elektryczność" [literally: "that you are drinking electricity"]. The inflected form of the predicate completes and sharpens the blurred boundaries of grammatical categories present in the original. Possible readings of "drinking", which may be seen as part of a 
truncated sentence: "I am drinking," "you are drinking," "one is drinking" or "they are drinking", or as a gerund, are narrowed down to only one meaning. Ultimately, the smooth, unbroken flow of the words (as if imitating the pleasant flow of the divine liquid) is turned into a series of clearly separated gulps.

If one wanted to retain the original liquidity, one could opt for comparably ambiguous words and word order, for example: Nektar wyobraź sobie pić elektryczność: pokarm bogów or Nektar wyobraź sobie picie elektyczności: pokarmu bogów. Apart from deleting the commas, the major modification in the proposed version would be the use of the infinitive pić [to drink] or picie [drinking; the gerund, which never constitutes a part of the inflected verb form in Polish but is always understood as a noun]. ${ }^{8}$ The omission of commas would loosen the syntax and allow the reader to connect wyobraź sobie [imagine] with either nektar or pić/picie [nectar; and drinking], consequently restoring the unbroken flow and ambiguity present in the original. In fact, in this case the discredited technique of "word for word, literal translation" would have come in handy, as my modified version is nothing else but such a rendering.

Another possible modification could entail using the infinitive wyobrazić sobie [to imagine]. This would bring about a slight difference in tone. Bloom's imagine sounds colloquial and intimate; since he is addressing himself, he doesn't need to speak in full sentences. The two infinitives in the proposed modification: Nektar wyobrazić sobie pić elektryczność would sound as a crude, almost pre-verbal stage of the protagonist's reflection, a mass of (grammatically) undifferentiated particles to be swallowed and digested.

Why did Słomczynski not choose to omit commas if the sentence could be improved on so seemingly effortlessly? Perhaps in this case their addition can be put down to his use of a subordinate clause rather than a more awkward gerundial phrase. ${ }^{9}$ Polish punctuation is quite strict in this respect since commas are always required before all subordinate conjunctions. But in other, similarlooking sentences, the translator sometimes retains Joyce's omissions, as in the following example, when Bloom is thinking how he would check whether the statues of goddesses in the museum have assholes: "Bend down let something fall see if she" ( $U$ 8.930; 1961 Random House Ulysses, 177;). ${ }^{10}$ Again the sentence mimics a continuous, fluent movement of Bloom's imagined gesture. The Polish translation reads as a word for word version: Pochyle się upuszcze coś zobacze czy ona. It describes a series of consecutive actions in the first person future forms of verbs, so it is a string of coordinate clauses, in which

\footnotetext{
${ }^{8}$ Wyobrazić sobie (to imagine) is a reflexive verb in Polish, hence sobie meaning "oneself".

${ }^{9}$ Another, important agent at play might have been the proofreader and the language editor. Polish conventions of punctuation are strictly controlled, so editors have a very strong tendency to regulate unconventional, idiosyncratic styles of punctuation because they see them as glaringly "wrong" or "erroneous".

10 The quote comes from the 1961Random House edition of Ulysses because Słomczyński, who translated Joyce's novel in the years 1958-1969, used the editions containing this version of the sentence. When he revised his translation slightly in the early 1990's, he did not collate it with Gabler's text, not having access to it then (information based on my personal conversations with the translator in the 1990's).

The Gabler edition of 1986 has "Bend down let something drop. See if she" (8.930), while his synoptic editon of 1984 notes a variant without a full stop separating the two sentences, marked as tC (vol. 1, NY and London: Garland Publishing, 1984; p. 368).
} 
every element is of equal importance. Commas seem redundant, and their absence may indicate either an equal status of the described actions or proximity in time, which may explain why the punctuation marks have been omitted here.

Incidentally, this sentence provides us with another example of the discrepancy between the marked pronoun drop in English, signaling clearly that this is an interior monologue. By contrast, its only marker in Polish is the truncated final phrase czy ona, "if she", and the lack of commas. This may be another reason why they are omitted here; otherwise, it would sound like standard, stylistically unmarked language.

Unlike English, Polish, described as a so-called "pro-drop language,"11 is highly elliptic. Some classes of pronouns are typically dropped from a sentence since they can be easily inferred from the context. In fact, in Polish the "baseline rule for pronominal subjects is to elide them" 12 because it has several features allowing for such an easy elimination. These include rich verbal and nominal inflection; free word, theme-rheme (topic-comment) discourse structure order; subject-verb agreement, and present, past and future tense verbal inflection indicating the person. ${ }^{13}$ So the subjectless sentence, so clearly marked in English, is quite typical in Polish. Consequently, the effect of incompleteness, mental shorthand, and intimacy is weakened in the translation.

The features listed above are also responsible for greater syntactic flexibility. Since in Polish inflectional endings define relations between words in an utterance, different parts of a sentence can be juggled around much more freely than in English. Nearly any word order is grammatically acceptable, and usually perceived as "correct" or "natural", if sometimes emphatic, by native speakers. On the one hand, this often allows for an effortless, nearly automatic rendering of Joyce's idiosyncratic, iconic syntax into Polish, but on the other, it makes it more challenging to create some "special effects" of Joycean style.

When one considers samples of interior monologue in the Polish translation of Ulysses, one is struck by the fact that associative, strongly elided or truncated sentences of the English original are often rendered in rather naturally sounding Polish. Take, for example, a passage in "Hades," in which Bloom's thoughts flow freely from one association to another: he reflects on Latin prayers, funeral accessories, priests, decaying bodies and deadly gas they emit. In English, Bloom's thoughts quite clearly stand out as incomplete, inner speech. Some sentences lack the subject, others - the verb or punctuation, which makes them sound like an anacoluthon. The corresponding passage in Polish is also recognisable as the interior monologue. However, the degree of grammatical incompleteness is much less noticeable. Sentences such as "Makes them feel more important to be prayed over in Latin" (6.602), or "Want to feed well, sitting there in the morning in the gloom kicking his heels waiting for the

11 Hadumod Bussmann "pro-drop language," Routledge Dictionary of Language and Linguistics. Trans. and ed. by Gregory Trauth and Kerstin Kazzazi. 2nd printing (London : New York : Routledge, 1998), 393. See also "Null subject parameter," The Concise Oxford Dictionary of Linguistics, P. H. Matthews (Oxford University Press, 2007), Googlebooks, Web. Accessed 4 Oct 2012; and "Chapter 7. Null Subject Phenomena," Steven Franks, Parameters of Slavic Morphosyntax (New York, Oxford: Oxford University Press, 1995), 287-332.

${ }^{12}$ Marjorie McShane, "Subject Ellipsis in Russian and Polish," Studia Linguistica 63 (1) 2009: 98-132, p.109.

${ }^{13}$ McShane, "Subject Ellipsis...", Table 1. "Typological features of Russian and Polish related to ellipsis," p.106. 
next please" (6.604), in which the omission of the subject is a mark of inner speech, translate into grammatically correct "Wydaje im się, że są ważniejsi, kiedy się tak nad nimi modli po łacinie" (P/S 115) and "Trzeba się dobrze odżywiać, siedząc tam przez całe ranki w mroku, zbijając bąki, czekając na następnego, proszę" (P/S 115). The Polish reader does not notice any conspicuous colloquialisms or ungrammaticalities in these sentences, except perhaps the final "please" (prosze). But this gap between the English and Polish cannot be easily closed because it results from inherent differences between the two languages, which makes it challenging for a translator to find satisfactory solutions.

\section{HUNGARIAN (Erika Mihálycsa)}

Nektár, azt hiszem, mintha villamosságot inna az ember: istenek eledele. (H/G I 140)

[Nectar, I believe, (it is) as though one were drinking electricity: gods' food.]

Mintha elektromosságot innál: ambróziát. (H/Sz 216)

[As though you were drinking electricity: ambrosia.]

Nektár, mintha elektromosságot innál: istenek eledele. (H/“C” $\mathrm{C}$ 173)

[Nectar, as though you were drinking electricity: gods' food.]

I think the three successive Hungarian versions illustrate well the passage from early translations attempting to render "contents", to ones more sensitive to issues of style and linguistic expression. Although all three versions listed here restitute the narrative control missing from the original and ineluctably fill in the syntactic blanks (the only alternative to finite structures here would be the use of the infinitive in Hungarian, which would require the same level of grammatical control), there is a marked difference between their degrees of "righting" and back-normalizing. Gáspár, whose literal translation in many instances quite surprisingly emulates Joyce's anomalous syntax although such is probably a result of literalizing translation, rather than of some assumed translatorial programme - here explicitates syntactic relations: the parts of the sentence are rigorously delineated by commas; the impersonal "imagine" of the original, addressing, as it were, an imaginary listener, is even "back-translated" to Bloom himself ["I believe"], while the non-finite "drinking" is rendered in a sub-clause with a generic subject. Szentkuthy's 1974 version trims the original - leaving out "nectar" itself (mentioned two sentences earlier) that starts off the chain of associations; his sentence also reads as a perfectly grammatical construction, as the Hungarian verb ending encodes the personal pronoun. The "Corrected" version reintroduces the noun "nectar" in the front position; the clause that follows, preceded by a comma, reads as an explanatory tag and displays none of the elliptic, porous nature of the original. With this version nevertheless the effect of the mental process, starting on "nectar" that first occurs to Bloom and triggers the association to electricity, is emulated; yet the comma that separates "nectar" from the clause that follows reinscribes textual and narrative control. 


\section{Now begging letters he sends his son with. (11.648)}

Richard Goulding - Bloom thinks observing him at the table in the Ormond dining room - has seen better days but is now in reduced circumstances and has come down on the social scale. This "process-sentence" could be seen as a psychological sequence: Goulding was once well off. Now reduced to $\{1\}$ begging $\{2\}$ begging letters now, $\{3\}$ he sends them $\{4\}$ through his son. The syntactic indeterminacy and anomalous structure of the original phrase forces translators to clarify it. Could the inchoative sequence be preserved it translation? Do other languages offer a possibility of some syntactic/semantic indeterminacy that could elicit a similar defamiliarizing effect?

\section{GERMAN(ic) and Romance languages (Fritz Senn)}

It would be futile to decree, dogmatically, that translators ought to adhere slavishly to the word order of an original ad visible as it might be. The syntactic nature of the various languages alone would militate against such a rule. At the same time the sequence of thought impacts as sequence can have its justification.

When "Now begging letters he sends his son with" (11.648) is rendered as "Ora fa portare in giro dal figlio lettere che bussano a quattrini" (I/DA 368) the scenario has changed and "begging", the key impact, moves into the background. Some translations adhere to this order:

Jetzt Bettelbriefe, mit denen er seinen Sohn losschickt (G/W378)

$\mathrm{Nu}$ bedelbrieven waar hij zijn zoon mee op uitstuurt (D/V 317)

Ahora cartas mendigando que mande con su hijo (S/S 298)

Even with the same order, some translations are more reasoned:

Desormais ce sont des demandes d'argent qu'il fait passer par son fils" F/A 341)

A présent ce sont des demandes d'argent qu'il fait porter par son fils (F/M 267)

The begging (supposed to be the triggering impact) has evaporated.

Others do not treat the sequence as the (possible) mental progress that has been posited here:

$\mathrm{Nu}$ sender $\{4\}$ han sin søn $\{3\}$ ud med tiggerbreve $\{1,2\}(\mathrm{Da} / \mathrm{B} \mathrm{I}, 321)$

Ora fa portare $\{4\}$ in giro dal figlio $\{3\}$ lettere che bussano a quattrini $\{2\}(\mathrm{I} / \mathrm{DA} 368)$ 


\title{
DUTCH (Erik Bindervoet and Robbert-Jan Henkes)
}

\author{
Nu bedelbrieven waar hij zijn zoon mee op uitstuurt. (D/V 317) \\ $\mathrm{Nu}$ bedelbrieven waar ie z'n zoon mee op pad stuurt. (D/C\&N 291) \\ $\mathrm{Nu}$ aan 't bedelen brieven waar ie z'n zoon mee stuurt. (D/B\&H 332)
}

Starting from the premise that the interior monologue sentences (IM) are all meaningful, structurally, and not just words glued together, it would entail that every IM sentence could be expanded to a comprehensible grammatical (not necessarily correct) complete entity. Especially for the more equivocal and less clear IM bits, this is a good starting point for a translator: ask yourself what the entire sentence would sound like, before the mind densifier started working. In reality (but what is reality, we are living in literature here, not in reality), the process would go the other way round: the mind grammar is the "real" grammar, the verbal expansion is there for the benefit of understandability. But still.

How does the sentence arrive? The paragraph runs: "Bloom askance over liverless saw. Face of the all is lost. Rollicking Richie once. Jokes old stale now. Wagging his ear. Napkinring in his eye. Now begging letters he sends his son with. Crosseyed Walter sir I did sir. Wouldn't trouble only I was expecting some money. Apologise." (11.646-649)

It is probable indeed that the word "begging" here performs a dual function: Richie now is begging (that would be the first thought of Bloom after his observations of Richie) and sends his son with begging letters. If it were only "begging letters," the "now" would be mentally placed further up in the sentence: "Begging letters he sends his son with now." But a caveat is in its place: Morel, supervised by the master, translates: A présent ce sont des demandes d'argent qu'il fait porter par son fils. ("At the moment it is begging letters he makes his son carry around.") Although "begging letters" is usual English. An example encountered only yesterday, in the standard work Irish Eccentrics by Peter Sommerville-Large: "When the begging letters failed he had to resort to subterfuge" (125).

Vandenbergh translates the sentence under scrutiny: $N u$ bedelbrieven waar hij zijn zoon mee op uitstuurt (317). Which would be floatable, in an inflated state, as: $\mathrm{Nu}$ [schrijft hij] bedelbrieven waar hij zijn zoon mee op uitstuurt - that is, "Now [he is writing] begging letters which he sends his son to go around with." The idea that Richie is "now begging" is lost.

Claes \& Nys translate: $N u$ bedelbrieven waar ie z'n zoon mee op pad stuurt (291). Which is essentially the same as Vandenbergh, except for the expression op pad sturen, which makes slightly smoother reading than Vandenbergh. Not that this is always a criterion for a better translation, on the contrary, smooth reading runs the risk of degenerating into smoothed-out reading. But no "psychological sequence."

To preserve the possibly forked function of "begging," we translated: $N u$ aan 't bedelen brieven waar ie z'n zoon mee stuurt. Which would read, expanded: $N u$ [is hij] aan 't bedelen [met] brieven waar ie z'n zoon mee stuurt. In this case, the stress will remain on the fact that Richie is begging now, and 
not, as in previous translations, immediately skip to the letters of supplication themselves, which is Bloom's next mental step.

\section{ROMANIAN (Elena Păcurar)}

Acuma-l trimite pe fiu-său cu scrisorile cu care cerșește pomane. (Ro/I I 327)

[Now he's sending his son with the letters with which he's begging for alms]

The Romanian translation resolves the explicit reading of Golding's pauperism by first expanding the sentence and adding words that not only force the understanding of the sequence in an unambiguous direction, but also results in a tautological illustration of social status. The English morphological ambiguity of "begging" disappears in the Romanian version of cerșește (synthetic verbal form which also implies a subject - he's begging), which has no adjectival value. The verb is followed by the object (alms) so as to further clarify Golding's condition. As in the English original, the reference to the present - as opposed to an implied glorified past - is fronted in the Romanian translation (Acuma - 'now'). A hint at Golding's critical condition and the critical/ironic eye recording it is interestingly expressed by certain colloquial forms: acuma (an informal version of the standard acum) or the disappearance of the definite article and the hyphenated noun-possessive adjective unit in fiusău (his son).

\section{POLISH, RUSSIAN (Jolanta Wawrzycka)}

Żebrzące listy, z którymi posyła swego syna (P/S 212)

[Begging letters, with which he sends his son].

Unlike other translations, this sentence in Polish omits Joyce's "Now" which alters the semantic dynamics of its Polish rendition, as back-translation indicates. If a psychological stipulation is that Richie Goulding was once quite well off and is now reduced to begging or sending begging letters through his son, then the Polish translation takes this psychological subtlety away by turning "begging" into a qualifier of "letters." Restoring "Now" - teraz - would not necessarily change much, unless "begging" is rendered as żebrzac, or an adverbial participle, rather than zebrzace, an adjectival participle in plural (both appearing as "begging" in English). A possible solution, Teraz żebrzac listy posyta przez syna [Now begging he sends letters through his son], approximates the dynamics of Bloom's thinking, though the Polish zebrzac refers to Goulding and eliminates the possibility of also referring to the letters.

In Russian, we have: Да сынка посылает со слезными прошениями $(\mathrm{R} / \mathrm{H} \& \mathrm{H} 212)$ [And his little son he sends with plaintive petitions]. There is no ambiguity here that it is the son who is sent around with begging letters; the Russian translation smoothed over the potentially problematic "begging" by rendering it as an adjectival qualifier of "petitions," following the mores of grammar and declension.

A similar example of jostling thoughts and impressions in an interior monologue passage rendering is found later in the same episode: 
Suppose that communal kitchen years to come perhaps (8.704)

Przypuśćmy, że kiedyś po latach kuchnia bẹdzie społeczna (P/S130)

[Let's suppose that sometime after [many] years kitchen will be communal].

In this phrase, syntactical and semantic subtlety registers either Bloom's thinking about a possibility of communal kitchens as a future solution to feeding the masses, or Bloom's apprehension that he might have to rely on one some day. The subtleties have been ironed out in Polish into a clean sentence whose meaning departs from the original. This is a good example of how studying a translation allows the original phrasing (with all its ambiguities) to come much more prominently to the surface.

In Russian the sentence reads:

Представим себе когда-нибудъ будет коммуналъное питание (R/H\&H 130)

[Let's imagine that some day there will be communal feeding].

As is the case in Polish, this translation misrepresents the original's semantic range.

\section{HUNGARIAN (Erika Mihálycsa)}

Kolduló leveleket küldözget a fiával. (H/G I 219)

[Begging letters he keeps sending with/by his son.]

Tarháló leveleket küld a fiához a. (H/Sz 338)

[Cadging letters he sends to his son the/to/for...]

Most? Tarháló leveleket küldözget a fiával. (H/“CC” 265)

[Now? Cadging letters he keeps sending with/by his son.]

Once again, reproducing the original's word order comes perfectly natural to Hungarian where (agglutinated) words are, however, syntactically far less adaptable and pliable: "begging" can only be read in this position as an adjective qualifying "letters", whereas thanks to the flexibility of English, the opening word could also suggest a participle, part of a verbal phrase registering, as it were, a mental process from "Now [he is] begging" to "begging letters [he sends]". Although at face value all Hungarian translations emulate the original's word order, only with some sleight of hand could these be said to dramatize the impact of a chain of associations, not to mention the defamiliarizing effect of the English phrase. While the first and the recent version, in obeisance to Hungarian syntax, turn the English "process sentence" into a neat, normative Hungarian structure, Szentkuthy's 1974 text displays a translator's error that opens a veritable "portal of discovery". At a cursory look, Szentkuthy seems to resort to an occasional practice we also find in Joyce - of leaving sentences unfinished, thus contributing to the effect of inchoative groping in the interior monologues that breaches grammatical rules; the ending on a definite article suggests that a complement/(in)direct object was meant to follow. However, the verbal postposition (the equivalent of Indo-European prepositions) makes the 
son not the carrier of the letters, but their addressee, and this blatant mistake unravels the source of translatorial misreading: Szentkuthy apparently interpreted Joyce's sentence as "begging letters", "he sends his son", "with [object of prepositional phrase missing]". There is a significant difference between the "shortmind" reading, suggested here, that approximates a psychological sequence [Goulding, once well-off, is now reduced to $\{1\}$ beg Now reduced to $\{1\}$ begging $\{2\}$ begging letters now, $\{3\}$ he sends them $\{4\}$ through his son ging $\{2\}$ begging letters now, $\{3\}$ he sends them $\{4\}$ through his son] and accordingly is distinctively odd, as if syntax were lagging behind the multiple associative links, and the reading suggested by Szentkuthy's translation, which seems derailed exactly by this oddity, preferring instead a more straightforward or plausible, if erroneous, path.

\section{Then about six o'clock I can. Six. Six. Time will be gone then. She. (8.853)}

The existing translations opt for a simple, unproblematic, "the time will be gone by 6". There is a possibility, however, that the thought is shortmind for something like: [by that] time [he=Boylan] will be gone then, with the customary mental elision of Boylan. If this reading is correct the question is, how could it be rendered? Obviously not all translators interpreted the sentence as it is done here.

\section{GERMAN(ic) and Romance languages (Fritz Senn)}

Joyce's shortmind non-grammar may trigger some deciphering here. Bloom is wondering about when he might return home and find the coast clear: "Then about six o'clock I can. Six. Six. Time will be gone then" (8.852). Many translations in print seem to take it at nearly face value, that by then, six o'clock, time will have passed - which of course is hardly worth remarking:

Dann ist die Zeit vorbei. (G/G 198)

Dann ist die Zeit um. (G/W 244)

Alors tout serait dit. (F/M 171)

Du temps aura coulé sous les ponts. (F/A 254)

Il tempo sarà passato. (I/DA 236)

El tiempo habrá pasado entonces. (S/T 198)

Dan is de tijd voorbij. (D/B\&H 208)

Enrico Terrinoni's Italian version of 2012 follows the direction indicated above: "Se ne sarà andato per allora", with an implied "he" (in the 
verb form "sarà" (I/T 190). ${ }^{14}$ Similarly, one may detect a suppressed personal pronoun in the Portuguese, "O tempo já vai ter passado daí" $(\mathrm{Po} / \mathrm{G} 323)$. The issue is whether "will be gone" refers to time or an elided "he".

Frequently, Bloom's jostled thoughts, as in "The full moon was the night we were Sunday fortnight exactly there is a new moon" (8.587), are often taken apart and neatly rearranged, often with added punctuation:

Vollmond in der Nacht genau am Sonntag vor vierzehn Tagen, ja, jetzt ist Neumond. (G/G 190)

Vollmond war doch an dem Abend, wo wir, Sonntag vor vierzehn Tagen war das, genau, dann ist jetzt Neumond. (G/W 234)

La pleine lune c'était la nuit que nous étions, exactement dimanche quinze jours, c'est nouvelle lune. (F/M 164)

La pleine lune c'était la nuit qu'on était exactement dimanche il y a quinze jours, c'est la nouvelle lune. (F/A 244)

\title{
DUTCH (Erik Bindervoet and Robbert-Jan Henkes)
}

\author{
Dan ik zo tegen zessen. Zes, zes. Dan is de tijd wel voorbij. Ze... (D/V 203) \\ Dan kan ik zo tegen zes uur. Zes. Zes. Dan is het wel voorbij. Zij. (D/C\&N \\ 187)
}

Dan kan ik rond zessen. Zes. Zes. Tijd zal wel weg zijn dan. Zij. (D/B\&H 208, future 4th ed.)

A beautiful sequence of fourteen very simple words, with a twist. As usual, Claes \& Nys ironed it out: their "time will be gone" has become a very simplistic "then it will be over" (Dan is het wel voorbij). No mystery, no suggestion of anything, labouring under the assumption that there is only one right explanation and therefore only one right translation. They are so scared of making mistakes that they make the biggest of them all, that of making Joyce one-dimensional.

Vandenbergh shows more feeling for the poetic weirdness of the phrase, more or less like the other translators: "then time will be over." In the end we also fell for that: Dan kan ik rond zessen. Zessen. Zessen. Dan is de tijd voorbij. Zij. Which is a bit of a pity, because during the Transworkshop in Zürich we probably came up with a better solution, a very literal one: Dan kan $i k$ rond zessen. Zes. Zes. Tijd zal wel weg zijn dan. Zij. Which keeps both the truncated thought ([tegen die] tijd zal [hij] wel weg zijn dan: 'by that time he will be gone then') and the poetic attraction in tact. Translation is an ongoing, perhaps neverending process. So: still more work for the future fourth edition.

\footnotetext{
${ }^{14}$ This may owe something to the translator's attending the Zürich workshop, May 2010, where such issues were discussed.
} 


\title{
FRENCH (Tim Conley)
}

\author{
Alors tout serait dit. (F/M 171) \\ Du temps aura coulé sous les ponts. (F/A 254)
}

\begin{abstract}
Bloom sometimes conflates "time" with "Boylan," not just because he has the fateful appointment with Molly that day, but because the morning after the lovers met at a bazaar dance, Bloom is unable to explain the thematic structure of Ponchielli's "Dance of the Hours" because Molly is preoccupied with thoughts of Boylan. "Time will be gone then" is a good example: Bloom prefers not even to think the man's name. The phrase sounds a little like an English cliché, but it isn't, though Aubert's translation offers a cliché: time past as water gone under the bridge, and the allusion to Boylan is also flushed away. Morel's idiomatic version is even more oblique: "then everything would be said." (What said, and by whom? Are we to suppose Boylan a rich conversationalist? Or is a confrontation being planned here?). The use of "alors" there has potential, though. Joyce's line could be an allusion to an old maypole song: "To the maypole let us on, / The time is swift and will be gone." If so, "Alors le temps aura disparu" might be a serviceable translation, since it keeps the lyric, allows "time" to stay in the line, and its action can easily apply to Boylan, whom Bloom hopes will have "disparu."
\end{abstract}

\section{SPANISH (Guillermo Sanz Gallego)}

\author{
Se habrá ido entonces. (S/S 201) \\ El momento habrá pasado entonces. (S/V 211) \\ El tiempo habrá pasado entonces. (S/T 199)
}

In effect, the interpretation of the original is "the time will be gone by then" in the two more recent translations, by Valverde and Tortosa. The difference between the two lies in the translation of "time", which appears in a neutral way in the latter, as if referring to time passing by. The former, however, makes use of a formulation that relates to a framework or the timing for something to occur.

Salas Subirat has opted for translating it by means of a third person singular which can be understood as "he" or "she". An interpretation of this third person as "time" seems unlikely due to the verb used, "irse", which requires an active subject. If the interpretation of the original must take into consideration Bloom's specific syntax during the passages that display his interior monologue, and, as a result, the original sentence is expected to be understood as "[by that] time [he=Boylan] will be gone then", then Subirat's version seems to be the most appropriate for conveying such message. Nevertheless, regarding form, Bloom's characteristic formulation does not appear in any of the three Spanish translations. 


\section{ROMANIAN (Elena Păcurar)}

Timpul va fi trecut atunci. Ea... (Ro/I I 207)

[Time will have passed / will be past (by) then. She...]

The Romanian translation can be said to express certain ambiguities, but none in relation to Boylan. The sentence echoes a meditation on the passage of time rather than on the bitterness of jealousy or sentimental unrest. The sequence va fi trecut can be read in two ways: either as a future perfect verbal form (will have passed) alluding to the completion of a temporal cycle, of an action in a given period of time (something will have been finished by then) or as a noun-verb-noun sequence (will be past) playing on the imminent time flow (what is present now will be a past then).

\section{POLISH, RUSSIAN (Jolanta Wawrzycka)}

Później o szóstej będę mógl. Szósta, szósta. O tej porze będzie po wszystkim. Ona... (P/S 133)

[Later at six I will be able to. Six o'clock. Six o'clock. Then at that time\} everything will have passed. She...]

Unlike the unproblematic solutions of many other translations that suggest, "the time will be gone by six," Senn's prompt above stipulates that the following shortmind operates here: "by the time six comes around, [Boylan] will be gone then." "Time" in its verbal form, as OED will confirm, also means "to ascertain or note the time at which (something) is done or happens; to note the time occupied by, or the duration of (action, etc.)." In the light of such variants as "Today. Today. Not think" ( $U$ 8.1063), ${ }^{15}$ Bloom's shortmind here could be read as: "Time [for the liaison that I gave Molly and Boylan] will be gone then." The Polish translation emphasizes the happening that will have ended by six, tapping to Bloom's thinking quite successfully, I would argue. As does the Russian translation:

Потом можно часов в шестъ. Шестъ. Шесть. Тогда уже будет все. Она. (R/H\&H133) [Later will be possible at six o'clock. Six. Six. Then everything will be. She.]

The proper phase for "six o'clock" would be "в шесть часов" rather than the jumbled “часов в шесть," though the distortion does express Bloom's state of mind quite well. Once again, the second phrase, "Then everything will be" conveys, as does the Polish translation, the passing of an event-in-time (rather than just time) that Bloom works very hard to banish from his thoughts.

\section{HUNGARIAN (Erika Mihálycsa)}

Addigra elmúlik az idő, a nő... (H/G I 138)

[By then time will have passed, the woman...]

15 Although they appear later in Ulysses, the five occurrences of "at four" in "Sirens" ( $U 11$. $188 ; 305 ; 309 ; 352$; 392) reinforce Bloom's thinking about Boylan's visit in terms of liaison rather than just time. 


\author{
Az idők teljessége. Ö... Nő... \\ [The fullness of time. S/He... Woman...] (H/Sz 213) \\ Addigra elég idő telik el. Ö pedig. (H/“CC” 171) \\ [By then sufficient time will have passed. And s/he.]
}

As most translations, two of the three Hungarian versions explicitate the phrase "Time will be gone then" as having time for its subject, and preclude the possibility of an elliptic reading, "[by that] time [he= Boylan] will be gone then". (Szentkuthy falls back here on his practice of substituting a phrase of his own making, to cover up some place in the original that is either too contextually obscure, or deemed to be too unadventurous - one might wonder which case it was here.) The first two translations top this with another explicitation, albeit one that sits awkwardly with Bloom's interior monologues: since Hungarian has no genders and no gendered pronouns, "she" - obviously connoting Molly - is rendered not with the third person singular, non-gendered "o"" but with the noun "woman" (incidentally, chiming in with "ido": time) - a way Bloom would hardly ever refer to Molly and which would derail reading in the direction of other females on Bloom's mind, or even - as with Szentkuthy "on the female form in general developmentally" (16.1449). The "Corrected" text reaches a compromise: the Hungarian phrase "by then sufficient time will have passed" has an elliptic structure and suggests psychological unease, unwillingness to define and articulate "then" - presumably the consummation of Molly's adultery - thus neither the act nor the actor(s) are named; the phrase "o" pedig" is even more indeterminate than in the original, as it might equally - and equally plausibly - refer to Boylan or Molly. The effect is, understandably, of a raw chord being touched, of an urge to push a painful and stubbornly recurring, thought out of mind.

\title{
5. Because the acoustics, the resonance changes according as the weight of the water is equal to the law of falling water (11.981)
}

Bloom's memory of what he once learned in physics is sketchy and not entirely adequate to account for the noise of falling water in a chamber pot in the example above. The jumble is the result of several steps, something analogous to: Acoustics: the resonance changes [how exactly?]/ the resonance changes according as .../[new start] the weight of the water ... [in formulae something is always] "equal to"/ [there is a] law of falling ["bodies"] / [in this case] water. The "law of falling water" is a spurious configuration. The whole, moreover, recalls an earlier, equally faltering attempt:

Because the weight of the water, no, the weight of the body in the water is equal to the weight of the what? Or is it the volume is equal to the weight? It's a law something like that. (5.39)

The challenge in translating the passages above is that they are both scrambled thoughts with intrusions and echoes of similar convolutions. 


\section{GERMAN(ic) and Romance languages (Fritz Senn)}

Wollschläger suggests tentative reasoning with an embedded question, spelling out and clarifying what is implied in the original:

Weil die Akustik, die Resonanz wechselt, ähnlich wie das Gewicht des Wassers gleich ist dem wie war das Gesetz vom fallenden Wasser (G/W 391).

Goyert's German rendering is a complete but nonsensical sentence:

Weil die Akustik, die Resonanz sich ändert, je nachdem das Gewicht des Wassers gleich dem Fallgesetz des Wassers ist (G/G 317).

Other translations seem to achieve the semblance of a meaningful sentence put together by associative fragments:

Parce que l'acoustique, la résonance change selon que le poids de l'eau est égal à la loi de la chute des liquides (F/M 276=F/A 406)

Por la acústica, la resonancía cambia en la medida en que el peso del agua es conforme a la ley de la caída del agua (S/T 324)

Perché l'acustica, la risonanza cambia secondo che il peso dell'acqua è uguale alla legge di gravità dell'acqua (I/DA 381)

Perché l'acustica, la resonanza cambia secondo il peso dell'acqua è uguale al principio della gravità dell'acqua (I/T 289)

\section{DUTCH (Erik Bindervoet and Robbert-Jan Henkes)}

Omdat de akoestiek, de resonantie zich wijzigt al naar gelang het gewicht van het water gelijk is aan de wet van vallend water. (D/V 328)

Doordat de akoestiek, de resonantie verandert naargelang het gewicht van het water gelijk is aan de wet van vallend water. (D/C\&N 401)

Omdat de akoestiek, de resonantie verandert naar al naargelang het gewicht van het water staat gelijk aan de wet van vallend water. (D/B\&H 333, 4th ed.)

If it is true what Bloom thinks, that the resonance in acoustics changes at the same rate that the weight of water equals the law of falling water, then surely he is bound to get a Nobel Prize. However, in the context of Bloom's most innermost thoughts, the passage is most of the time understood to say that acoustics, according to Bloom, have a law just like water, only he doesn't know the exact definition, and he is jumbling the two about a bit. The expanded version of this piece of shortmind would read something like: "Because the acoustics, the resonance changes according [to something, the same way] as [water? the medium it goes through? no, hm, er -] [yes, maybe something along the lines of the law of the weight and volume of water, what was it, I was just thinking about it on my way to the Post Office, in Chapter 5, the "Lotus Eaters", lines 39 to 42, if I remember well] the weight of the water is equal to [or was it 
the volume, there is a law like that, what is it called?] the law of falling water [no, falling bodies, ah whatever, I'll come back to it later...]."

You see, incidentally, that the mind's grammar, as we move along in the day, gets progressively more expandable, because there are more and more things to remember and impressions to ruminate about. You can also see how incredibly economical, even stingy, a writer Joyce is. He could have written a much longer book, if he had pumped up every flashing neuron in Bloom's brain and had done to the inner workings of the mind what Proust had done to the explications of people's unwitting actions, relentlessly pushed on by their dark will.

Neither Vandenbergh nor Claes \& Nys see the mind gap between the first (acoustics) and the second (watery) part of the sentence. Vandenbergh: Omdat de akoestiek, de resonantie zich wijzigt al naar gelang het gewicht van het water gelijk is aan de wet van vallend water (328). Claes \& Nys: Doordat de akoestiek, de resonantie verandert naargelang het gewicht van het water gelijk is aan de wet van vallend water (301). Both "grammatize" the sentence, making the second part subjunctive to the "according as" preposition. But "according as" is no preposition, it doesn't say "according to": Bloom is groping his way round a vaguely (mis)remembered analogy of natural laws of acoustics and water, and stops short after "according". He does not go so far as to say that the resonance changes at the same rate as "the weight of water is equal to the law of falling water," whatever that may be. Moreover, there is a noticeable mind comma after "is equal to" - and this also should be (at least virtually, with hindsight) noticeable in the translation.

Bindervoet \& Henkes: Omdat de akoestiek, de resonantie verandert naar al naargelang het gewicht van het water gelijkstaat aan de wet van vallend water. The hesitation becomes clearer now by the fumbling, in Dutch, of the preposition naargelang, contaminating it with al naar gelang which mean two slightly different things. But, for the future fourth edition, 'twould be equally better to make the new thought felt after "according as" by inverting, as Dutch does, the verb: staat gelijk aan signals that this is a new clause, not a subclause, dependant on the first: Omdat de akoestiek, de resonantie verandert naar al naargelang het gewicht van het water staat gelijk aan de wet van vallend water. Translations are never finished, they are just lain aside, to appropriate the famous saying of Paul Valéry.

\section{HUNGARIAN (Erika Mihálycsa)}

Mert az akusztika, a visszhang aszerint változik, ahogyan a víz súlya egyenlő a szabadon eső víz törvényével. (H/G I 228)

[Because the acoustics, the resonance changes depending [comma] on how the weight of the water is equal to the law of falling water.]

Ez is az akusztika miatt van, a rezonancia változik a víz súlyának megfelelően, amelyik mindig egyenlő a kiszorított víz súlyának a törvényével. (H/Sz 350) [This too is because of the acoustics, the resonance changes according to the weight of the water, which is always equal to the law of falling water.]

Mert az akusztika, a rezonancia a víz súlyának megfelelően változik, ami egyenlőa szabadon eső víz törvényével. (H/“CC” 274) 
[Because acoustics, resonance changes according to the weight of the water, which equals the law of falling water.]

All three Hungarian translations could testify, to varying extents, to a prevalent practice in literary translation - of standardizing, normalizing, rhetorically upgrading passages in the original that seem strange, awkward, faulty even. From underneath the surface of verbosity there emerges a syntactic no-direction, as if the narrative voice were struggling to put a scrambled thought into shape, with the result of falling back upon linguistic automatisms, in the event losing track of the idea. Instead of the expected accurate definition of some law of acoustics, the sentence is deflated and ends in a nonsense statement (the weight of the water being equal to the law of falling water). If one looks at the three Hungarian versions, one will not spot much of the original's effect of "as-you-go-along-ness" - of phrases being scraped together as the narrative phrase proceeds, into seemingly coherent text. Whereas Gáspár's 1947, fairly literal version still allows for an emendation in hindsight in the opening, the tendency to upgrade and stylize can best be seen in and Szentkuthy's translation: not only does he flesh out the original's opening non sequitur into an explanatory phrase, but due to the the subordinate structure at the centre, his version reads rather like a rigorously polished period, in contradistinction to the awkwardly stumbling original phrase. Only the "Corrected" version retains something of the original's ad hoc, thought-in-progress quality - however, due to a feature of Hungarian grammar by which verbal and noun postpositions (suffixes) encode person, number, case as well as direction, the (syntactic) additive effect of the original cannot be carried through.

\section{Anyhow, upon weighing up the pros and cons, getting on for one, as it was, it was high time to be retiring for the night. (16.1603)}

Bloom is "weighing up the pros and cons" and realizes that it (time) is "getting on for one" and that "it is high time". But the initial participial construction - which leads to the expectation that Bloom (obviously the implied subject) after "weighing" is also "getting on" — is forgotten, and the subject has shifted, whereby the construction collapses. Anyhow, upon weighing up the pros and cons [who is weighing?] getting on for one [looks like a parallel subordinate clause], as it was [the opening construction is lost sight of and a main clause begins without reference to the opening and now dangling "upon weighing"...], it was high time to be retiring for the night.

In "Eumaeus", as-you-go-along impressions are often stylized, ad hoc, into seemingly coherent narrative. Beneath the episode's tumescence of tropes, prolixity and linguistic automatisms, patterns of "shortmind" may be occasionally detected. To achieve the right kind of wrongness remains a tightrope act and more of an ideal than a practicality, as it shows in a particularly maladroit sentence above. 


\section{GERMAN(ic) and Romance languages (Fritz Senn)}

In the translations the aborted construction is straightened out and is replaced by transparence; sometimes a (necessary?) subject is introduced: "one", "man".

Auf alle Fälle, wenn er das pro und contra erwog und alles genau so sah, wie es wirklich war, war es höchste Zeit, aufzubrechen, denn es war schon spät (G/G 664)

Doch wie dem auch sei, wenn er das pro und contra erwog, war es, da es auf eins zuging, die höchste Zeit, sich zum Schlafe zurückzuziehen. (G/W 827)

Quoi qu'il en soit, comme à force de peser le pour et le contre on se rapprochait d'une heure du matin, il était grand temps de se retirer pour la nuit. (F/M 586)

Comunque, pesati i pro e i contro, dato che ci si avvicinava alle una, era ormai ora di ritirarsi per la notte. (I/DA 853).

Jedenfalls aber war es, wenn man das Pro und das Contra abwog, nachdem es ja schon auf eins zuging, hohe Zeit, sich für die Nacht zur Ruhe zu begeben. (G/W 827)

Cependant, après avoir pesé le pour et le contre, comme on approchait d'une heure, il était grand temps de se retirer pour la nuit. (F/A 975)

\section{ITALIAN (Enrico Terrinoni)}

In ogni modo, soppesando i pro e i contro, visto che oramai era quasi l'una, era tempo di chiudere la serata e di ritirarsi. (I/T 629)

Comunque, pesati i pro e i contro, dato che ci si avvicinava alle una, era ormai ora di ritirarsi per la notte (I/DA 872).

In my version, I did not introduce subjects in order to rectify the syntactical oddity of the sentence. Thus, we still don't know who is weighing, and the ambiguity seems to me to be kept in this case. The rest of the sentence translates almost directly into Italian without any major losses, which confirms my view that, Italian being the language in which Joyce would express himself for much of the time during the day with his family, he often wrote almost naturally employing the syntactical structures of Italian. The results of this are no doubt highly defamiliarizing for the English-speaking reader. Something similar happens with the first pages of "Oxen", whose syntax is modeled on Latinate syntax. Therefore, translations of Ulysses in Romance languages directly mirror the syntactical structure of the original, making us lose somehow the estranging effect the text has on an English-speaking reader - or even on any speaker of other Germanic languages. 


\section{ROMANIAN (Elena Păcurar)}

Oricum însă, cîntărind argumentele pro și contra, ținând seama de faptul că se apropiau ceasurile unu, era într-adevăr vremea să ne gândim la culcare. (Ro/I II 291)

[Anyhow, upon weighing up the pros and cons, taking into consideration that it was almost one o'clock, it was high time we thought about going to bed.]

The Romanian language manages to preserve a partial ambiguity around the subject(s) of the sentence by using two gerund forms (weighing, taking); the impersonal connotation of the gerund form is dropped towards the end of the sentence, where a plural subject ('we') is inserted. It is not unusual, though, for Romanian to illustrate impersonality by a first person plural pronoun, especially in scientific texts. The pseudo-scientific style of Eumaeus might allude to this kind of plural, impersonal subject.

Impersonality and ambiguity are also abandoned in the translation of getting on for one (se apropiau ceasurile unu -'it was approaching hours one'), where the obsolete time reference, in the plural, not only renders the official style of the episode, but also elides any trace of Bloom's getting on for anything.

\section{DUTCH (Erik Bindervoet and Robbert-Jan Henkes)}

In elk geval, het voor en tegen afwegend, daar het al tegen enen liep was het hoog tijd zich voor de nacht terug te trekken. (D/V 727)

Aangezien het al tegen enen liep was het, als men de voor- en nadelen tegen elkaar afwoog, in elk geval hoog tijd om zich ter ruste te begeven. (D/C\&N 689)

Hoe dit ook zij, na de voor- en de nadelen gewikt en gewogen te hebben, en het al tegen enen liep, zowaar, werd het hoog tijd om op te breken voor de nacht. (D/B\&H 748, 4th ed.)

Like all of "Eumaeus", this sentence is a feast for faultfinders, sniggering, that is, not sneering. Unfortunately not so in the previous Dutch translations, unless you take in account the big mistake, the greatest, most irredeemable fault of all, that of not trying to reproduce the Bloom-like or flowerful (as we say in our native mother tongue) effect that Joyce tried to achieve in this chapter, according to Francis Bacon's (the painter of that name) wonderful adagio: destroy what you can do easily.

Especially in the case of Claes \& Nys there is an unwillingness, a repugnance almost, to enter the portals of discovery, i.e., to make a mistake, even if it has to be done on purpose, probably because they are afraid the blunder will be blamed on them. Every fibre in their translator's body resists doing something out of order, out of line, something strange, incorrect or improper. As if you could almost hear them thinking: do we really have to wreck this sentence? Can't we just get on with the business of telling the story? It's a kind of self-censorship that takes the fun out of the translation, and for us it would have taken the fun out of translating itself. And in some ways it is 
almost worse than censorship or a ban, because it makes the book a very weak tea rather than an emetic, which was the blurb Judge Woolsey gave the book in his monumental, momentous, groundbreaking decision that opened up the sluices for publication in the U.S. Once more the fear of not being understood, in other words, their missed underestimation of the reader, takes the upper hand. Their Aangezien het al tegen enen liep was het, als men de voor-en nadelen tegen elkaar afwoog, in elk geval hoog tijd om zich ter ruste te begeven would translate something like this: "Since it was almost one o'clock, it was in any case, if one weighed the advantages and disadvantages, high time to retire for the night." You can hardly tell the difference with the Dutch language they employ in the rest of the book. That's probably the best we can say about it.

So we thankfully took over the clichés they used, probably unwittingly, because they use them everywhere - you can rely on them to go for the most common, the meanest denominator. In this sentence we have the very ugly voor- en nadelen for "the pros and cons", where de voors en tegens would have been the "better" translation for this cliché.

Vandenbergh forced the mistake a bit by depluralizing it: het voor en tegen: In elk geval, het voor en tegen afwegend, daar het al tegen enen liep was het hoog tijd zich voor de nacht terug te trekken - that is, clumsily but literally backtranslated: "In aly case, weighing the for and the against, as it was approaching one o'clock already it became the highest time to retire for the night."

We wholeheartedly tried to do it wrong and to uglify it by introducing another definite but rather inconspicuous particle, causing a chain reaction of repetitions (gewikt en gewogen ... en het al...) and the sentence going haywire, which both Vandenbergh and Claes \& Nys tried to camouflage by inserting the throwaway subject "men" ("one" or "they"): Hoe dit ook zij, na de voor- en de nadelen gewikt en gewogen te hebben, en het al tegen enen liep, zowaar, werd het hoog tijd zich terug te trekken voor de nacht. In the next edition we might change zich terugtrekken voor de nacht, which is a typical Claes \& Nys cliché, and of course used by them, for op te breken voor de nacht, two expressions glued together, which is wrong. And therefore right. (In this chapter.)

The wide scope of the above comments, their attention to details and nuances, including divergences - all most appropriate in the case of Joyce - also show a basic imbalance in judging the work of translators. Each problematic item is given a lot of space; in Zürich it was accorded an incommensurate amount of time. But consider for a moment how much effort translators in actual practice (assuming they also have to make a living) can afford to devote to an item of a few syllables. Or, if they could, how many years a translation of Ulysses would take to finish. Discussing niceties of translation is a fascinating scholarly activity but, at heart, a luxury that translators in the real world just cannot afford.

Many of the samples aired above, and many more discussed in Zürich, were often not noticed in, especially, earlier translations or, if they had come under attention, might not have been understood in the same way. There are always so many possible aspects in each single case, with new insights or speculations in the offing, that it would be unfair to fault translators on missing 
out on one single facet, no matter how important it may seem to individual readers.

A side issue emerged from the samples tossed around: punctuation, which of course has its local and often very strict rules in every language. One might question if the interior monologue, or shortmind, in its nature can contain any sort of punctuation at all since it always implies a pause, a stop in the current of thoughts. Punctuation is essentially a controlling device that runs counter to an uncontrolled flow of impressions and associations - one reason presumably for Joyce to leave them out entirely in "Penelope."

Fritz Senn

fritzsenn@mac.com

Zurich James Joyce Foundation

Erika Mihálycsa

erika.mihalycsa@gmail.com

PhD, Professor, Babes-Bolyai University, Romania

Jolanta Wawrzycka

jolanta@radford.edu

PhD, Professor, Radford University, USA 